\title{
Reconceiving the Theology of Procreation in Response to Stigmatisation of Childlessness ${ }^{1}$
}

Gladys Wang

Presbyterian Church in Cameroon

Abstract: This article, based on the author's doctoral research, offers atheological response to thetraditional attitudes towards childlessness within the Bakossicommunity ofSouthWestCameroon. Researchrevealsaprevalentnegativeattitudetowardsthose — bothmenandwomen—whodo nothave children. This stigmatization is often reinforced within Christian communities by a reading of scripture that interprets the command to 'be fruitful and multiply' as referring exclusively to biological reproduction. In contrast to this, an African cultural feminist hermeneutic can be used to argue for a more holistic interpretation of scripture, one that draws out God's concern for family, community and creation.

Keywords: Childlessness • Bible • African • Feminist • Cameroon

\section{Introduction}

In many African communities, procreation in marriage is presumed to be the fundamental principle for the institution of marriage. A successful marriage should be "fruitful." The reason for such preconception is often based on the premise that God in creating human beings gave them the mandate to "go and multiply" (Gen.1:28a). Therefore, like their counterparts elsewhere, childlessness in marriage among the Bakossi community in South-West Cameroon is a serious problem confronting many couples. To many Bakossi, both Christians and non-Christians, the Bible remains a standard reference point in issues of faith and daily experiences. Furthermore, the Bible has become, for ordinary readers in Bakossi and other African societies in general, a resource bank or a reference book that helps them cope effectively with their daily struggle for survival, liberation and life. As a result, the Bible has continued to feature in contemporary religious, political and socio-economic discourse in Africa through theologians and non-theologians. My focus in this article is to rethink the theology of procreation as the basis of the institution of marriage. My context centres on the empirical data gathered from childless couples in the Bakossi community and the Christian pastors I have interviewed. It should be noted that, given the high density of Presbyterian Churches (PCC) in the Bakossi area, the pastors interviewed are all from the PCC. Ethnographic analysis suggests that the family is the most important institution in Bakossi society. The family is the context in which customs, traditions and cultural values are taught and the place where religious rites and rituals are performed. As a result, it is deemed unthinkable to live without somehow participating in producing new members of the Bakossi family. Therefore, when a couple does not fulfil this culturally assigned duty, it results in negative consequences for said couple. Furthermore, the stigmatisation that childless couples often face in society instigates feelings of personal shame and guilt towards God for not fulfilling the command given to humankind. 
The methodology and theoretical lens used in this article is the African Feminist Theology of Cultural Hermeneutics (hereafter AFTCH), which will be utilised in relation to the pastoral issues raised by childlessness. According to Justin S. Ukpong $(2000,24)$, this approach is one in which the context of Africa itself forms the subject for the interpretation of the Bible. This means that African social-cultural perspectives inform the conceptual framework of interpretation. Following AFTCH enables a critical approach to both biblical and African cultures so as to promote a commitment to liberation and the wholeness and enhancement of life in the community at large (Oduyoye 2001, 14 and Kanyoro 2002, 10).

Therefore, in the first part of this paper, I identify the challenges of marital childlessness from empirical data collected among the Bakossi community in South-West Cameroon. The results of this study reveal that although childless couples face social and cultural stigmatization, the consequences differ depending on a person's gender, geographical location, profession and faith perspective. The predominant concern in the second section of the paper is to reconceive the theology of procreation within the marital relationship. To that end, I fuse the themes developed from my interpretation of childlessness. I problematize childlessness from the interpretations of certain biblical passages made by childless couples, the wider community and PCC pastors. I argue that childlessness has social implications in Bakossi culture and the line between childlessness as a socio-cultural issue and as a religious problem is very thin. Furthermore, I argue that the command to "go and multiply" was not a weighty affliction but a gift from God to humanity to partake in caring for the things God created. Many childless couples in the Bakossi community (and PCC pastors) solicit help from the Bible in order to seek and reassure themselves that God is interested in human reproduction. I therefore search for alternative interpretations, voices and ideas concerning childlessness or childbearing within various biblical texts. Here, it is important to emphasize that the biblical texts discussed will be read from the perspective of pastoral theology. In sum, in order to reconceive the theology of procreation, this essay utilises a contextual reading of the Bible (AFTCH) to uncover the appropriate pastoral response to childlessness. ${ }^{2}$

\section{Challenges of Childlessness in Marriages}

Procreation to safeguard the lineage is the main purpose of married life in the Bakossi community. Thus, childbearing is a major duty of both husband and wife. Another central function for having children is to give couples the social status of parenthood. A person is recognized as mature and responsible after reproducing and nurturing a child to adulthood. Consequently, childless couples face the threat of being called 'immature, 'irresponsible' and 'inadequate' and are easily stigmatized as deviant or irresponsible adults. The importance given to procreation shapes social, cultural and religious dynamics in the community and paves the way for childless couples to experience deep stress, shame, sorrow and social stigmatisation. The result is often the loss of self-esteem and feelings of disappointment, pain and fear. Childless wives and husbands both experience these feelings. It is important to note, however, that the challenges facing childless married couples may also differ based on how they relate to culturally-established gender roles and expectations.

The pressure for couples to become parents comes mostly from relatives of the men. This is because the men's family members want to secure the survival of their lineage. Principally, only a man's biological male child can bear his name and thus secure the survival of his lineage and be a legal heir to his property. The absence of a male child in a man's life therefore threatens the very existence of his being.

Connected to the procreation of a male child is the patriarchal ascription of family headship. The first son is the natural heir of the father. If a man fails to father a child, his relatives may give the family stool to a younger brother who has fathered children. ${ }^{3}$ When deprived of the position as family head due to their inability to procreate, childless men say they feel they are less of a man. Childless couples are, in fact, unable to go through the transition of adolescent to adulthood, since childbearing is the culturally accepted norm that proves maturity.

While men are expected to father children, as in most other communities, women are blamed more often than men are for childlessness. The women in this study often accepted the blame for marital childlessness without any undergoing medical diagnosis. I understand that such self-blame probably stems from the fact that in the traditional setting, women see childbearing as a primordial role for women in marital relationships. However, childless women who are educated and earn a salary are also typically blamed for the absence of children in their marriage relationship. They are suspected of having undergone several abortions during their years of pursuing an education, which had affected their procreative abilities. Childless women living in a rural setting are likewise 
accused of being unable to bear children due to having had abortions or engaging in witchcraft-activities passed on to them by their mothers. Thus, accusations are directed to a woman's lifestyle and her family for practicing witchcraft. Accordingly, the absence of children in a marriage causes women to re-examine their past lifestyle and careers to identify possible causes of their childlessness. Yet, when husbands are accused of being the cause of childlessness, they typically are not ready to accept the blame because the larger society tends to believe that male impotence is uncommon. In addition, and unlike the case with women, the gravity of childlessness for men varies among educated and uneducated men. What might account for such differences is that educated men link their identity to and form it through their profession, while uneducated men who live in a rural community derive their social identity and status from begetting children.

Childless women face public confrontation and abusive language regarding their inability to have children more often than men do because women interact in social and cultural gatherings more than men do. Coming together to help with food preparation on occasions like childbirth, naming ceremonies, marriages and funeral celebrations, to mention but a few, is a sign of solidarity with other women. During these gatherings, women engage in conversations connected with childrearing, during which those who are childless are expected to be silent. If they speak, they are berated by the others for their lower status as immature females. Thus, many childless married women, especially those residing in villages, live an unhappy life shaped by self-pity and lack of self-esteem.

Some childless women choose to avoid such community gatherings, but this is difficult to do due to the community's social structures. The songs sung only magnify their feelings of emptiness. The songs sung in the celebration of a newborn child hail the mother for accomplishing a great task that is expected of every woman. The words of one such song are Nyo achya wee oo, wee echya mod luduu (ampee), Mod mod esue ne mekaa megen, asuu.., ne mekaa, mod kenhog esue ne mekaa megen. A literal translation into English is 'Your mother gave birth to you, so that you also can give birth to another. Let no one return empty-handed.' The lyrics imply that the purpose of human existence is for each member of the community to produce new members, and no one is expected to die without reproducing. Lyrics like these render childless women speechless and leave them with a feeling of being a failure to the community.

Childless men also often avoid certain social gatherings. One is the annual clan celebration known as Ndieh, during which family heads and some selected elders of the village are expected to pour libations on behalf of their families. This occasion reminds them of their procreative failure and the loss of status as a family head. Childless couples are always singled out to step forward during community prayers, when an elderly male is asked to invoke the spirits of ancestors to enable the childless couple to conceive. Childless couples lamented that such a public display of their need leaves them feeling shame, as though they are misfits. Therefore, they may avoid participating in such gatherings.

An individual's path through life is monitored, marked and celebrated before their birth, throughout their life and in death and thereafter. Lifecycle rituals enable individuals to begin to rework their sense of self and their relationships as required by changes during life. Childless couples are sometimes prevented from participating in such rituals and are often stigmatised when participating. Childless men are prevented by cultural tradition from participating in religious acts like the pouring of a libation or carrying out a similar ritual relating to children, since these are normally performed by the family head. A childless man is not perceived as a medium through whom others may receive blessings. Socially and religiously, he is seen as an imperfect person who is incapable of being a goodwill ambassador to the community. Childless women are prevented from participating in the celebration of a woman's first pregnancy. Other situations from which they are excluded include participating in conversations regarding childbearing and rearing, burial rituals, exuberant funeral celebrations and being elevated to the status of ancestor.

Public meals and storytelling for entertainment are important and valued social activities but also occasions for discrimination against childless couples. The preparation of meals and the telling of jokes are mostly welcomed by those who have children. The idea is that parents are most capable of telling stories about what it means to be a human being. Childless people are perceived to lack this ability and insight. As a result, childless couples feel dishonoured, stripped of their dignity and integrity and treated as outsiders.

Cultural prescriptions and restrictions also affect childless men, but the manner in which this takes place is different from how it affects women. Men are expected to remain calm, even under the worst adversity. This prescribed virtue of masculinity dictates that a man should react with less emotion and distress. Men are not expected to shed tears in public, especially in the presence of a woman. If he does, a man loses his attribute of being male and brave. My interaction with the childless men, however, demonstrated that although they often 
appear to be less affected outwardly, they are struggling to meet the culturally prescribed role of being strong people who can comfort their wives. I observed that childless men might seem calm about their situation in public because nobody engages in close conversation with them to understand their plight. As soon as I engaged them in deep conversation about how they felt, they expressed their vulnerability. Clearly, then, childless men feel distressed about such cultural prescription, but they conceal it more than childless women do.

Adoption is an unlikely alternative to childlessness. Due to the belief in the existence of spirits and witchcraft possession among the Bakossi and in most African communities, many childless couples eschew adoption. Belief in the transition of family spirits from one generation to another stops childless couples from adopting children whose family spirits they do not 'know.' The child is suspected of being an evil spirit, which could spell misfortune for them instead of resolving their predicament. The same concern surfaces in connection with using modern technology in reproduction. They fear that children born through medically-assisted fertilization may possess a family spirit that does not belong to the family of either the wife or the husband.

A couple may raise their sibling's children, children belonging to extended relatives, and godchildren from their church or denomination. Nevertheless, Bakossi cultural perspectives consider such couples childless. Bakossi people define themselves first in terms of bloodlines and second in terms of family boundaries. In place of adoption and nurturing family children, the community offers childless couples the option for men to take a second wife, whom they hope will bear his biological children. Thus, polygamy remains the preferred solution when couples face childlessness. Although many childless couples I interviewed are against polygamy, they are forced to accept it by family members. While they do not appreciate the solution, many childless women said they stay in the relationship and share their husband with another woman to maintain economic security and the high social status of a married woman, which is considered a cap of honour. As a result, the relationship and intimacy that brought the couple together in the first place takes a secondary position to childbearing, which remains the primary function of marriage.

Some childless couples devote themselves to church activities. For women, these include teaching young children during Sunday services and being involved in choirs and other women's groups in the church. They are also allowed to become godparents to children, which gives them a parental position and responsibility within church circles. Women generally say they feel more comfortable in church-related activities than in cultural activities because discussions in church groups tended to centre on individual spirituality rather than family affairs and the raising of children. Local congregations also offer possibilities for childless couples to participate freely and fully in various social and leadership activities. For instance, within the Presbyterian Church, leadership is open to all men and women regardless of marital status or procreative ability. Moreover, other Christian brothers and sisters are reported to accept childless persons in leadership positions based on their skills and potential, not their ability to procreate.

Couples acknowledge they find comfort sharing their challenges with the pastor, who provides counselling and spiritual guidance. Couples in search for answers find comfort in pastors who refer to alternative scriptures that speak about the need to trust in God because God is the one responsible for humans' procreative ability. The above considerations notwithstanding, some myopic interpretation of scriptures on the importance of bearing children offered during church weddings leave some couples with mixed feelings. Some testify that when confronted with passages that speak about the importance of childbearing-for instance Psalm 127:3, stating that children are a heritage of the Lord and the fruit of the womb is His reward (KJV)—-they feel rejected by God. Such Scripture makes them wonder if they do not qualify to be recipients of God's blessings and gifts.

Overcoming the longstanding cultural assumption that the purpose of the institution of marriage is procreation necessitates a critical examination of both the cultural and religious interpretation of the theology of procreation.

\section{Reconceiving the Theology of Procreation}

During my interviews with childless couples, the majority explained they use the Bible as a source of strength. I observed, however, that the Bible plays a dual function-it is both a tool of oppression used by the Bakossi community against childless couples and a tool of liberation and comfort to childless couples and counselling pastors. Similarly, Oduyoye (1995) has argued that the Bible has been used in Africa as a trusted resource or tool to justify actions and to extend decisions governing the society and human relationships. She contends, "The Bible within the African context has been treated as an infallible oracle ... and Africans, so adept in their culture or morality, have a phenomenal memory for what 'the Bible says"' (Oduyoye 1995, 190). This widespread treatment of the Bible as an infallible oracle, coupled with a lack of contextual reading, has led to what I consider a misinterpretation of 
certain biblical passages by individuals, pastors and the wider community on biblical passages. Such readings hamper efforts to address the patriarchal attitudes entrenched in the Bible. In addition, there is a general lack of recognition of the gap between present-day contexts and those in place when the Bible was written, which ignores the relevance of time, context and generation.

In what follows below, I present some of the traditional interpretations of biblical passages that are frequently cited by Bakossi to support the view that the purpose for which God instituted marriage is the procreation of children. I ask, does childlessness signify a curse, a mark of imperfection, abandonment and punishment from God? I search for alternative interpretations and Scripture or passages that could put childlessness in a different light. To that end, I undertake a critical reading and interpretation of some of the biblical passages most cited in connection with childlessness and infertility. Next, I reject the validity of the traditional perspective, which holds that the failure of a couple to enact God's command to humanity to procreate results by definition in an unfulfilled life. Instead, I suggest that the biblical phrase in Genesis 1:28, 'be fruitful and multiply,' can be interpreted in multiple ways as far as marriage and childbearing are concerned. In my attempt to reconceive the theology of procreation, I then explore whether there are other biblical passages that offer alternative interpretations of procreation in marriage.

Cultural reading and interpretation of Genesis 1:26-28 in relation to procreation

And God said, 'Let us make mankind in our image, in our likeness, so that they may rule over the fish in the sea and the birds in the sky, over the livestock and the entire creature that move along the ground' (26). So God created mankind in his own image, in the image of God he created them; male and female he created them (27). God blessed them and said to them, 'Be fruitful and increase in number, fill the earth and subdue it. Rule over the fish in the sea and the birds in the sky and over every living creature that moves on the ground' (28) (NIV).

The hermeneutical principle applied by the Bakossi community and some PCC pastors to the phrase, "Be fruitful and increase in number, fill the earth and subdue it" drives home the point that remaining childless flaunts the basic assumption about why God created humanity and instituted marriage. This interpretation is prevalent not only among laypersons but is also found among clergy. One pastor I interviewed cited it as one of the commands that God gave humanity. He argued, "God instituted marriage for the enjoyment of man and woman but He also commanded them to be fruitful. Hence, childbearing is part of the reason for instituting marriage" (Rev. Kelvin, in discussion with the author. January 2018). Similarly, during a conflict between one of my interlocutors, Mrs. Ngallame, and her mother-in-law, the mother-in-law said angrily, "I see you going to all healing services organized by the pastor yet nothing is happening. If you were not a witch, then God would have answered your prayers since you got into this house. Did the Bible not say, 'Go and multiply?'” (Mrs. Ngallame, in discussion with the author. March 2017).

To suit her attitude, the mother-in-law of Mrs. Ngallame limited her interpretation of "be fruitful and multiply" to childbearing. In her response, Mrs. Ngallame quoted a different Scripture that gave her solace in her situation but also reflected her vested interest. She replied, "God's time is the best. How long did it take Abraham and Sarah to have their own child?" (Mrs. Ngallame, in discussion with the author. March 2017). She interprets the story as endorsing the need to be patient and await the time God considers appropriate.

The central question underlying their dispute is what it means to "be fruitful" in a marriage. Is fruitfulness limited to childbearing, or does it exceed this idea? By referring to Abraham and Sarah, Mrs. Ngallame is alluding to God as the one who gives children. In this regard, the Bible becomes a reference book and tool used to justify actions and biases, regardless of what their standpoints are. This is a "proof text" form of reading and interpretation of Bible verses. In biblical hermeneutics, the concept of "proof text" refers to holding a position on an issue and locating particular biblical passages to support it, without making room for an alternative reading (Asamoah-Gyadu 2007 , 458). Such use of a single, selected verse in strategic readings, interpretations and applications compounds the biased interpretation of the Bible. Rather, what needs to be done is taking contextual readings of biblical texts in conjunction with other related texts in order to see how suitably the text can speak in the present context.

The Merriam Webster dictionary defines'fruitfulness" to mean "producing good results or being productive." This denotes positive results from an action or an increase in productivity, which can be literal or figurative in meaning. If fruitfulness is taken in this productive sense, the command that God gave to the first couple cannot be limited to procreation or the production of children. Secondly, it is a general blessing to humankind that it is not limited to individual procreative ability. In a sense, humankind's posterity should extend to all corners of the earth. Fruitfulness also can imply other aspects of production, such as the cultivation of crops, the development of talents 
and caring for the rest of creation. Furthermore, in my understanding, the divine request that humankind take dominion over the rest of creation (Genesis 1:28b) does not in any way call for domination, but rather for responsible stewardship over other living creatures. Thus, being "fruitful" and "increasing in number" cannot be limited to the act of procreation as the sole reason for which humanity was created. Being fruitful and increasing in number can equally imply an increase in human talent for the wellbeing of the entire universe. For example, Jesus was born and raised a Jew. He was never married and had no children; he did not increase the human race, yet in his earthly life he fulfilled the law and plan of God perfectly by impacting the lives of those to whom he ministered (Matt. 5:17). In other words, his work bore fruits with a legacy that still lives on.

When the first creation narrative in Genesis 1:26-28 is read in conjunction with the second creation account in Genesis 2:18-"It is not good for man to be alone; I will make a suitable helper for him"-the establishment of marriage becomes a complementary union that is not principally for childbearing. I agree with Niditch's interpretation that the creation of woman was meant for closeness and the conjugal bond between the two genders (Niditch 1992, 13). If this relationship is to grow, it needs an enabling space for both the male and female to learn to love and complement each other in every aspect, without external pressure. The need to reproduce has frequently overridden the love and affection between spouses because of the cultural presumption that being childless in marriage flouts God's intention for marriage.

According to Genesis 1:26-28, humans are created equal and are to live in corporate solidarity, interdependent and interconnected. In this relationship of equality in gender, they are to procreate and have dominion over all other creatures. As God's creatures, both the male and female bear the special mark of God's image (imago dei) and are charged with the responsibility to care for the rest of the creation. Any degree of domination or suppression by one gender over the other falls short of the relational perspective God had for creating humanity. Male and female are two complementary sexes that determine humanness; they exist for each other, forming a human unity. Grudem $(2000,454)$ maintains that the creation of man as male and female shows God's image in harmonious interpersonal relationships and equality in personhood and importance. Introducing these interpretations to childless couples as well as the community at large can help the childless appreciate their interrelatedness more than their ability to procreate.

In the celebration of traditional Bakossi marriage, prayers are offered to the gods of the land to bless the newlywed couple with children and the abundance of the soil. In their prayers, people invoke both the spirit of the land (ancestors) and God Almighty from the Christian tradition. Failing to accomplish the desired reproduction, childless couples accordingly return to the spirits of their land and God Almighty. They say they pray for divine intervention and wonder why it takes God such a long time to answer their prayers. Several of the participants made statements like the following one voiced by Mr. Ngolle: "I rest my case with God ... He alone knows when this will come to an end. We wait on God who gives at his own appointed time" (Mr. Ngolle, in discussion with the author. March 2017). Pastors continuously try to imprint in the minds of childless couples that God is responsible for granting the gift of children and God reserves the right for whom He wishes. They also stress how God is all-knowing and has the ability to answer and grant the desires of people's hearts.

The interesting question here is whether God contradicts Himself by withholding procreative ability from a couple. If God gave the mandate to humanity to increase and multiply, as presented in the creation narratives, how can God then be responsible for closing wombs? In this respect, Abasili $(2015,592)$ has observed that many Bible commentators have questioned the credibility of the biblical author in attributing the closing of the matriarchs' wombs to God. "Surely," says Moyo, "there could have been other ways that the author would tell the story of mysterious birth, without bringing in the concept of barrenness and God's complicity in it" (Moyo 2006, 83). Contrary to Moyo's thinking, I argue that in the narrator's focus on mysterious birth in the concept of barrenness and God's complicity, the point is to prove the absolute control and mightiness of God in all human circumstances. The likely underlying motivation was to replace an older belief that the goddess Asherah was responsible for human reproduction. When monotheism developed, the role and attributes of all other gods needed to be shifted to Yahweh.

In the book of Psalms, we read, "Children are an heritage of the Lord: and the fruit of the womb is His reward" (Ps. 127:3). I suggest that one should be cautious not to interpret this to mean that those who do not have children are not blessed or that God is not hearing their prayers. Glahn and Cutrer have argued, "God blesses all of his children, but he chooses to distribute specific gifts differently. These gifts are not limited to children, nor are babies His "ultimate gift" (Glahn and Cutrer 1997, 131). Not only is God the giver of children, but He equally has a pre-knowledge of what the children will turn out to be in the future (Gen. 25:23). 
Another important aspect to examine theologically is the feminization of childlessness. On both the individual and social level, I found that women easily embrace the societal blame for childlessness laid on them because of their inability to negotiate the contradictory normative expectation within the family and community. In sharing with me their counselling experiences with childless couples, pastors pointed out that women are always the first to come to them for counselling or intervention in a family crisis regarding childlessness. A woman told one pastor, "My husband's family is threating to send me away because I cannot give them a child" (Rev. Willemon, in discussion with the author. September 2016). Another pastor remarked, "In this community men are never thought of as being infertile. Only women are. However, even in situations where the case may seem [so], it is easily covered up through the help of another male family member, or in the worst-case scenario, the family encourages the woman to search for help outside the family" (Rev. Helena, in discussion with the author. August 2016).

A few childless men, however, went against the social norm and admitted they might be the infertile partner. When asked by his family members to send the wife away because she could not give him a child, Mr. Ngallame refused and said, "What if I am the problem of our childlessness?" His response indicates that for some, childlessness is a collective family issue. His attitude echoes that of the patriarch Abraham in Genesis 15:2, who did not blame God for his wife's inability to conceive, but personalized it. He asked, "Sovereign Lord, what can you give me since I remain childless," not "since my wife cannot conceive." I agree with Fischer $(2012,17)$ that in the narrative, the problem of childlessness is initially discussed in reference to the affected male, not the affected female. In the wider story, the message is conveyed that their long period of barrenness was God's decision and action, not the fault of either Sarah or Abraham. God is responsible for the procreative ability of humans. The lack of children in the lives of biblical patriarchs and matriarchs can be read as a bigger challenge to men than women, because men needed a son to continue their lineage. Moss and Baden also argue that for both Abraham and Isaac, "prayers are for their names and their lineage, for family and the upholding of God's promise to become a great nation" (Moss and Baden $2015,34)$. It can thus be argued that the desire for offspring is not limited to a woman's desire for motherhood. Having children is very important to men for the sake of inheritance, lineage and legacy. In the Hebrew Bible, having children, especially a male child, is presented as necessary because without sons, one would effectively disappear from history (Moss and Baden 2015, 29).

In the section that follows, I reflect constructively on biblical texts that can be used to present readings that can offer meaningful pastoral care to childless couples. Building on the traditional interpretation of certain biblical passages by both childless couples and the wider community, I search for alternative biblical texts that speak differently about or even give a contradictory understanding of marital childlessness.

\section{Alternative Voices on Childlessness or Childbearing}

Are there any passages in the Old or New Testament that talk about those who are childless in a positive way? Yes, for instance in 2 Kings 22:14-16. In this text, Huldah is not defined by her procreative ability, but by her functional ability. The text does not specify that she and Shallum had no children. She might as well have been a mother also but that role was not necessary even in a context where having children for genealogies was appreciated. Huldah served God as a prophetess and keeper of the wardrobe in the temple in Jerusalem. She was a medium with whom kings and priests communed to seek God's answers to their problems, and her ministry defined her within her community. The story highlights the fact that a person's identity within his or her community has more to do with the services they render than their procreative ability. The text projects Huldah's dual identity as a prophetess and a wife of Shallum.

Although infertility is listed in the category of biblical misfortunes, (Deut. 28; Lev. 20:20-21; Jer. 22:30), seldom was it a punishment visited on an individual. Rather, infertility is a national curse laid on the children of Israel should they break the terms of the Sinai Covenant. In the Bible, infertility and other misfortunes such as sickness, famine and death are either attributed to divine punishment or given no explanation whatsoever. For instance, in the Abimelech narrative in Genesis 20:17-18, God imposes infertility as a punishment. On the other hand, the story of Hannah in 1 Samuel 1:1-11 shows that childlessness does not always result from a divinely enacted curse; by praying to God, she received divine intervention and bore many children. Whether childlessness is divine punishment or the result of a natural calamity, the underlying fact is that God is always part of the story and He has the ability to harm and to heal. Furthermore, in the Wisdom of Solomon 4:1 it is written, "Better to have no children yet to have virtue, since immortality perpetuates its memory; for God and human beings both recognize it." In this 
verse, we find childlessness is positively correlated with virtue, a category that would seem to be impossible in a context where infertility and divine punishment are inextricably linked (Moss and Baden 2015, 49).

Traditionally, much attention has been given to the blessing God pronounces in the creation narrative in Genesis 1:28, whereas very little attention has been given to a passage like Isaiah 56:3-5. Here we read:

Let no foreigner who is bound by the Lord say, 'The Lord will surely exclude me from his people'. And let no Eunuch complain, 'I am only a dry tree'. For this is what the Lord says: 'To the eunuchs who keep my Sabbaths, who choose what pleases me and hold fast to my covenant, to them I will give within my temple and its walls a memorial and a name better than sons and daughters. I will give them an everlasting name that will endure forever' (NIV).

The text, I suggest, can be interpreted to mean that not being able to participate in biological procreation does not mean that childless people are worthless. Implicitly, God talks positively about being childless in this passage. The focus is on the importance of immortality in eternity. Although childless people do not produce children who can remember them in their earthly life, God assures the childless of having a better remembrance than what they seek in this present life. This may indicate that people should strive for what is eternally given. Moss and Baden have suggested that if the people of the ancient Near East capitalized so much on the need to have sons to immortalize them, it was because "The ancient Near East was predominantly illiterate; for one's name to live on after one's death, there had to be someone to keep it alive. Memories and stories, which could be curated only in the minds of one's offspring, took the place of the letter, photographs, and home videos" (Moss and Baden 2015, 29). Although a person's immortality and memory seem to be dependent on having offspring, there are other ways to create memorials. For instance, doing charity acts within the community and adopting a child from an orphanage could be good ways of immortalizing oneself.

An issue that brought much concern amongst childless couples was immortalization. A childless male participant, whose duty as the sole male child of his parents was to have children, posed the question while crying, 'On whom do I stamp my image? Who will be there to remember me when I am gone?" (Mr Ekoti, in discussion with the author. May 2017). An alternative way of immortalizing life is represented in the example of Jesus. In his teaching, Jesus substituted traditional family ties for the eschatological community that shared his vision of a new, divinely-constituted family. Immediately after his baptism, Jesus's family life faded into the background and his public ministry and companionship became prominent. In Jesus's new definition of kinship relations, there are no boundaries. In fact, it goes beyond blood relationships (Moxnes 2003, 94).

To dismantle human boundaries, Jesus chose his disciples and established with them and through them a new kind of community based on heterogeneous kinship. It was a new household, which comprises all "those who hear the word and do it" (Luke 8:21). It was a new household of mutual concern, where those who are saved have the responsibility to save and serve others (Luke 10:5-12). In contrast to traditional family living, Jesus's followers created a more communal and harmonious living. In Acts 2:42-47, the believers were united in heart and spirit such that no one claimed any private ownership of property like one would see in the traditional family scene. Instead, they shared things in common and according to the needs of each member of this new community.

This biblical principle, if taken seriously, fits very well into the African philosophy of Ubuntu about communal solidarity. In principle, this means that interconnectedness, not childbearing, constitutes the essence of being human. To share and do for others is central to achieving good life and wellbeing. Hence, in this new dispensation of family, it can be said that happiness and joy are not limited to having children or making a family. I agree with the view expressed by Grant concerning life suffering and challenges: "we must interpret our circumstances in light of what we know about God, rather than interpreting God in light of our circumstances" (Glahn and Cutrer 1997, 116).

Childlessness or barrenness is one arena in which bodily healing is a controversial affair. Even though eschatology talks about transfiguration and healing, the condition of biological childlessness will not necessarily be reversed. For example, although the Ethiopian eunuch was baptized, his inability to procreate was never healed or transformed (Acts 8). His whole life transformed, and he became a means through which the word of God spread to other parts of the world (Moss and Baden 2015, 208). The lesson learned from this story is that though the eunuch's biological weakness made him an object of ridicule in society at the time, he gained not only personal dignity but also societal approval when he encountered Christ. 
In light of the reports from childless couples and pastors, women seem to face the most stigmatization and blame for the absence of children in a marriage relationship. I want to suggest a provisional reframing of the barren matriarchs in the Bible, like Sarah and Rebecca, and any other childless women. The sayings of Jesus about barren women constitute a reversal of what is traditionally held to be the function of women in Bakossi society, where a barren woman experiences shame and pity and is "othered" as imperfect or lacking something to complete her gender identity. In Luke 23:29b, Jesus uplifts the women who do not have children. "Blessed are the childless women, the womb that never bore and breasts that never nursed" (Luke 23:29b). This might imply that barren women had a special place in Jesus's message. In addition, barren women were among the early followers of Jesus's movement (Kartzow 2015, 403). By blessing childless women, Jesus was affirming that in the heavenly kingdom, those whom society considers the "other" shall be blessed and accepted. Moxnes suggests that Jesus's positive speech about barrenness and childless women signals a reversal of status here and now, where the eunuch, the barren women, and children who formally had no status in the society are all lifted up (Moxnes 2003, 94-95).

It is difficult for every couple in Bakossi and in Africa in general to extricate itself from the predicament of childlessness. As people mature, Bakossi socialization instils in them that they are to build their identity on begetting children as a sign of responsibility, maturity and personhood. The external environment becomes a guide to one's behaviour rather than a tool for confirming one's inner attributes. In such a case, the cross of Christ can be a good symbol from which the childless can draw strength. "The cross is a symbol of trauma and, having gone that way through to victory, a more balanced approach to childlessness would be to work with people so that, whether they have it or not, they can feel the empathy of Christ" (Asamoah-Gyadu 2007, 458).

Childless couples and most pastors made little or no reference to New Testament scriptures in connection with childlessness during my fieldwork interview sessions. I think this silence stems from the fact that the New Testament, unlike the Old Testament, does not have many stories about childless couples. Some interpreters of the New Testament have remarked that marriage and childbearing were not given great attention because the early Christians thought the end of the world was imminent. They rejected marriage and procreation in light of their eschatological thinking (Moss and Baden 2015, 206). In addition, because the eternal eschatological "fruits" were to supersede the blessings of offspring in this world, marriage and childbearing received less emphasis as something to seek out (Moss and Baden 2015, 208). On the other hand, Martin Dale $(2006,105)$ has argued, "The understanding throughout much of the ancient world was that marriage was a divine institution and its formation was for the purposes of legitimating and the control of procreation." Information about marriage and childbearing in the New Testament occurs most frequently in response to questions either posed to Jesus or Paul (Coleman 2004, 90). Although neither man was married as far as the New Testament reports, their teachings constitute a dominant guide in regard to marriage for their followers then and now.

In Mark 13, Jesus warns his followers about the dangers and horrors of the last days, especially the Day of Atonement. He emphasizes that on that day, children will rise against their parents and pregnancy will become a curse. Jesus says, "Woe to those who are pregnant and to those who are nursing infants in those days" (Mark 13:17). This is to be a day when biological bonds will not matter, making what humanity values and celebrates a curse. Moss and Baden argue that though procreation was intrinsic to the ancient notion of immortality, the rewards for the faithful who behave well do not include children (Moss and Baden 2015, 207). This ideology was borrowed from the prophet Isaiah's writing on salvation, where God promised to reward the eunuch.

For thus said the Lord to the eunuchs that keep my Sabbaths, and who choose the things that please me, and take hold of my covenant; Even to them will I give in my house and within my walls a place and a name better than of sons and of daughters: I will give them an everlasting name, that shall not be cut off (Isaiah 56: 4-5).

In their interpretation, Moss and Baden suggest "there can be no doubt that eternal eschatological 'fruits' supersede the blessings of offspring in this world" (Moss and Baden 2015, 208). This view suggests that one's heavenly positionality far surpasses one's earthly one. It reveals an anticipated reversal of culturally constructed reality wherein those who may have the advantage of fruitfulness or the disadvantage of childlessness in earthly life will be accorded different positions on the Day of Atonement. Thus, humanity should be more concerned with having their names written in "the temple of the Lord" than bearing children in their earthly life. In the eschaton, there will be neither marry nor are people given in marriage, which implies that procreation is limited to the earthly realm. 


\section{Conclusion}

In this article, I examined the implications of marital childlessness. The cultural and religious effects of childlessness on couples in the Bakossi sociocultural setting reinforces the already low self-esteem that childless couples experience. As a result, the childless couple faces a double grief and threat: the inability to have children and the cultural bias of low social identity. I argued that the Bible plays both a liberative and oppressive role, which depends on the interpretations people make of selected texts to sustain their preconceived ideas. After examining alternative interpretations of these same texts as well as other biblical texts that relate to the issue, I argued that childbearing is not the sole reason for the institution of marriage. Marriage is predicated on conjugal love, personal fulfilment and companionship, and procreation is not the essential component of a marriage. God has the ultimate power or control over humanity's procreative ability. God is the giver of children; the one who chooses to close or open the womb of a woman at his own appointed time. Therefore, human bodies are not to be viewed as biological machines. Instead, men and women should use the sexual relationship to unite two persons into a bond of "one flesh" together in the marriage covenant.

I also argued that there are several ways of immortalizing oneself. Doing charity or humanitarian service and showing love to God's creations should be the ultimate goal of human life. Searching through the Scriptures, I argued that the Bible speaks in many different voices and ways about childlessness. The new kind of family that both Jesus and Paul envision goes beyond biological lineage. For the sake of a higher calling, couples can be child-free, as was the case with some childless persons in the Bible, like Jesus and Paul. I opted for an approach to pastoral care and counselling that emphasizes the need to attain fullness in life regardless of an individual's ability to procreate. Notwithstanding the scientific explanations and research on solutions to infertility in humans, from a theological perspective, the Creator has the absolute ability to give life even to those who have lost hope (Gen 29:31; Ezek. 37:1-8). It is God's prerogative to allow and prevent conception. Birth, life and death belong solely to God and can only be controlled by humans via scientific technology to the extent that God allows. Therefore, childless couples should be encouraged to appreciate other abilities and potentials given to them by God. God created humanity to glorify God, and glorifying God means having a relationship. Therefore, procreation is not God's ultimate purpose for creating human beings.

\section{Notes}

[1] This article is an extraction of one of the chapters in my PhD thesis presented and defended at the Faculty of Theology at the University of Oslo-Norway, January 2020.

[2] Commentaries that combine the historical-critical method alongside African feminist and pastoral concerns are also utilised where these shed light on the biblical texts in question (see Oduyoye Mercy 1994; Oduyoye Mercy 1996; Kanyoro 1997; Kanyoro 2001; Nwachuku Daisy 1994; Nyengele Fulgence 2004; Acolatse 2011; Acolatse 2014).

[3] The significance of the family stool is that the family head sits on it and does ancestral veneration on behalf of the entire family. He is the mediator between the living and the dead-one who is blessed and can in turn be a source of blessings to others. Therefore, a childless man who is culturally perceived as a 'misfortune' cannot be given the right to sit on the family stool and perform rituals of blessings to others.

\section{Bibliography}

[1] Abasili, I.A. 2015. "Hannah's Ordeal of childlessness: Interpreting 1 Samuel 1 through the prism of a childless African woman in a polygynous family." Old Testament Essays 28(3): 581-605.

[2] Acolatse, Esther. 2011. "Christian divorce counselling in West Africa: seeking wholeness through reformed theology and Jungian DreamWorks." Journal of pastoral theology 21(1): pp.1-18.

[3] Andria, S. 2006. Colossians, 1 and 2 Timothy, Titus, James; generosity and solidarity. In Adeyemo, T. (ed) African Bible Commentary. Nairobi: WordAlive.

[4] Asamoah-Gyadu, K. 2007. "Broken calabashes and covenants of fruitfulness: Cursing Barrenness in contemporary Africa Christianity" Journal of Religion in Africa 37 (4): 437-360. 
[5] Coleman, Peter. 2004. Christian Attitude to Marriage: From Ancient Times to the Third Millennium. Great Britain: SCM Press.

[6] Dale, B. Martin. 2006. Sex and the Single Savior: Gender and Sexuality in the Biblical Interpretation. Louisville: Westminster John Knox Press.

[7] Glahn, S. \& Cutrer, W. 1997. When Empty Arms Become a Heavy Burden: Encouragement for Couples Facing Infertility. Nashville, Tennessee: Broadman \& Holman Publishers.

[8] Grudem, Wayne. 2000. Systematic Theology. Grand Rapids: Inter-Varsity Press.

[9] Fischer, Irmtraud. 2012. "The Story of Israel's Origin as a Woman's story." In Feminist Biblical Interpretation: A compendium of Critical commentary on the books of the bible and related literature, edited by Schottroff, L. \& Wacker, Marie-Theres. Michigan/ Cambridge: William B. Eerdmans Publishing Company, 15-32.

[10] Oduyoye A. Mercy. 1994. "Feminist Theology in an African Perspective." In Paths of African Theology, edited by Gibellin Rosino. SCM Pres Ltd, 166-81

[11] Oduyoye, A. Mercy. 1996. "Feminist Theology Africa." In Dictionary of Feminist Theologies, edited by Russell and Clarkson. Louisville: Westminster/John Knox Press, 112-14.

[12] Oduyoye, A.M. 2001. Introducing African Women's Theology. Great Britain: Sheffield Academic Press.

[13] Kanyoro, R. M. 2001 "Engendered Communal Theology: African Women's Contribution to Theology in the Twenty-First Century." Journal of Feminist Theology 27, 36-56.

[14] Kanyoro, R. M. 2002. Introducing Feminist Cultural Hermeneutics: An African Perspective. Sheffield: Academic Press.

[15] Kartzow, B. M. 2015. "Reproductive Capital and Slave Surrogacy: Thinking About/With/Beyond Hagar." In Bodies, Borders, Believers: Ancient Text and Present Conversations, edited by Grung, H. A. et al. Eugene, Oregon: PICKWICK Publications, 396-409.

[16] Moss, R. \& Baden, S. 2015. Reconceiving infertility: Biblical perspective on Procreation and Childlessness. United Kingdom: Princeton University Press.

[17] Moxnes, Halvor. 2003. Putting Jesus in His Place: A Radical Vision for Household and Kingdom. Louisville: Westminster John Knox Press.

[18] Moyo, Chiropfandzo. "A Karanga perspective on fertility and barrenness as blessing and curse in 1 Samuel 1:1-2:10" ThD diss. University of Stellenbosch South Africa, 2006.

[19] Niditch Susan. 1992. "Genesis". In The Woman's Bible Commentary, edited by Newsom, A. \& Ringe, H. London: Westminster John Knox Press (SPCK), 10-25.

[20] Nwachuku, N. Daisy. 1994. "Ritual and Symbols in the Healing of Infertility in Africa: Pastoral Counselling Response." In The Church and Healing: Echoes from Africa, edited by Kasonga Wa Kasonga et al. FrankfurtBerlin. New York: Peter Lang, 66-101.

[21] Nyengele, F. M. 2004. African Women's Theology, Gender Relations and Family SystemsTheory: Pastoral Theology Considerations and Guidelines for Care and counselling. New York: Peter Lang.

[22] Solevåg, R.A. 2013. Birthing Salvation: Gender and Class in Early Christian Childbearing Discourse. Leiden-Boston: Brill.

[23] Ukpong, Justin S. 2000. "Developments in Biblical Interpretation in Africa: Historical and Hermeneutical Directions." In The Bible in Africa: Transactions. Trajectories and Trends, edited by West, G. \& Dube, W. Musa. Leiden: Brill. 11-28. 